\title{
miR-I 95-Sirt3 Axis Regulates Angiotensin II-Induced Hippocampal Apoptosis and Learning Impairment in Mice [Corrigendum]
}

Fan X, Xiao M, Zhang Q, Li N, Bu P. Psychol Res Behav Manag. 2019;12:1099-1108.

The authors have advised due to an error at the time of figure assembly, Figure 1 on page 1103 and Figure 4 on page 1106 are incorrect. The correct Figures are shown below.

The authors apologize for these errors and advise it does not affect the results of the paper.
A

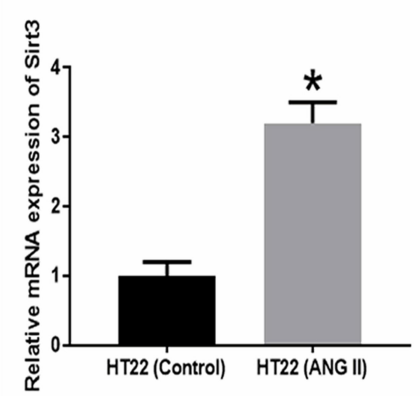

B

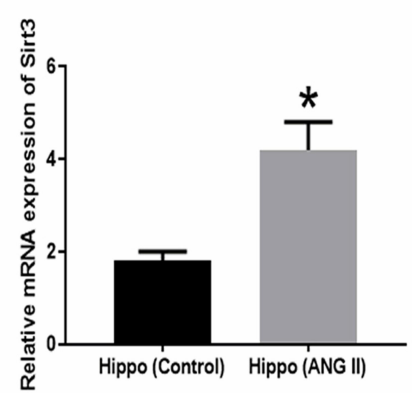

C

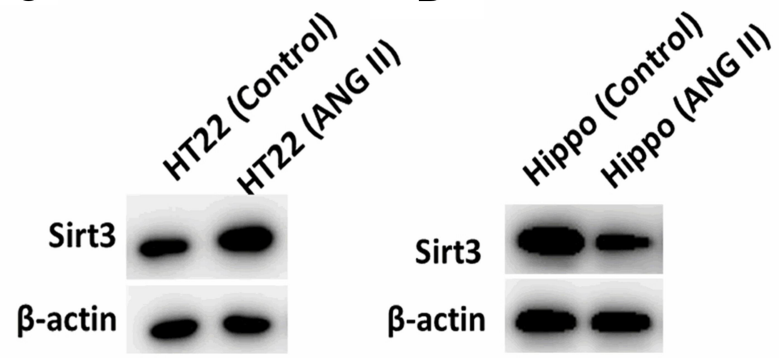

$\mathbf{E}$
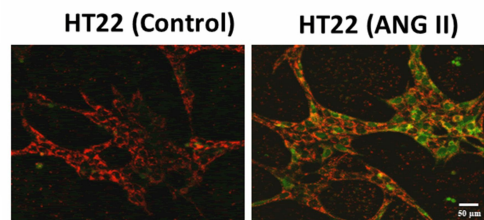

$\mathbf{F}$

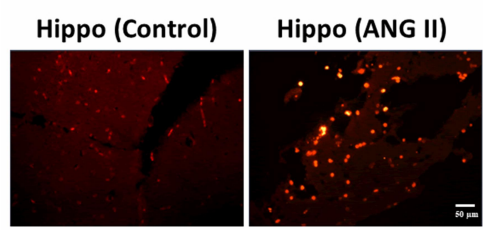

G

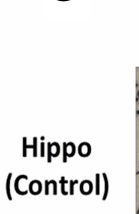

Bcl-2

Bax

CytC

caspase-3

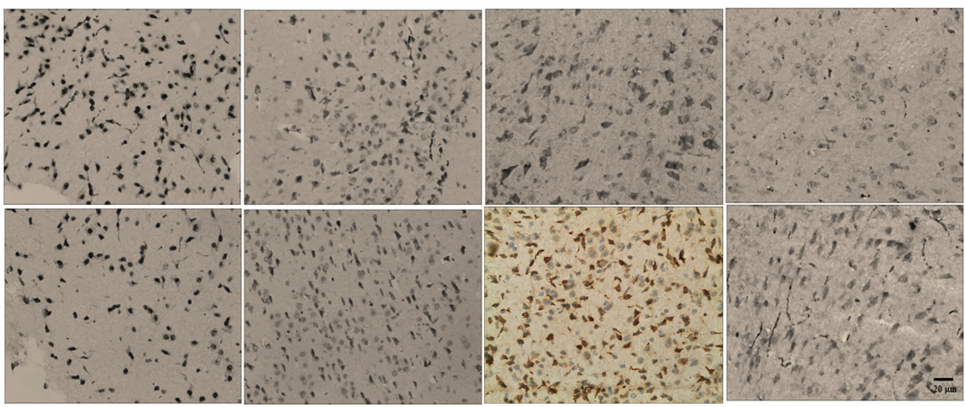

H
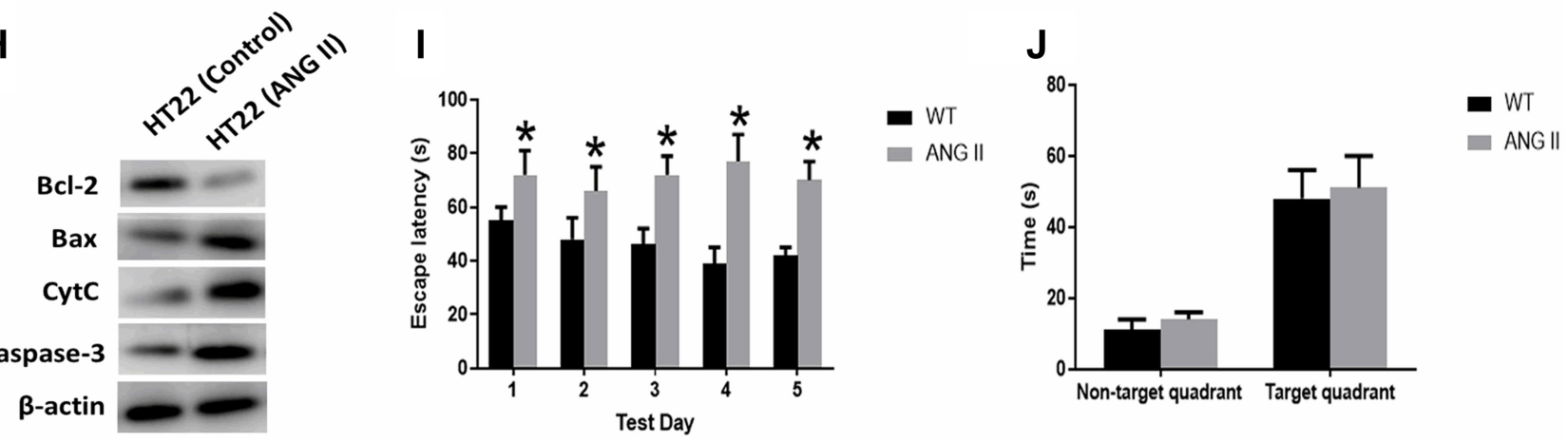

Figure I Effect of Angiotensin II (ANG II) on hippocampal apoptosis. (A and B) Sirt3 mRNA expression was measured by RT-PCR in HT22 cells (HT22) and hippocampal tissues (Hippo), respectively. (C and D) Sirt3 protein expression was measured by Western blot in HT22 cells (HT22) and hippocampal tissues (Hippo), respectively. (E) Representative images of HT22 cells stained with JC-I and the red/green fluorescence intensity ratio (scale bar=50 $\mu \mathrm{m}$ ). (F) Representative images of TUNEL staining indicating apoptotic cells in the mice hippocampal tissues (scale bar $=50 \mu \mathrm{m}$ ). (G) The expressions of apoptosis-related proteins measured by immunohistochemistry assay in the hippocampal tissues (scale bar=20 $\mu \mathrm{m}$ ). (H) The expressions of apoptosis-related proteins measured by Western blot in HT22 cells. (I) Spatial navigation testing assay. (J) Spatial memory testing assay. The data are expressed as the means \pm standard deviation ( $\mathrm{n}=6$ for each group) and asterisk $(*)$ indicate a difference at $P<0.05$.

submit your manuscript | www.dovepress.com 3 I 7
DovePress
http://doi.org// $0.2147 /$ PRBM.S30937|


A

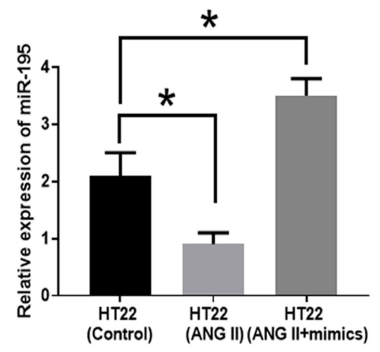

C

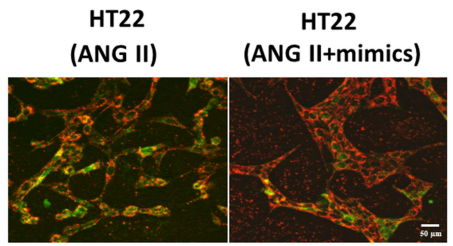

D

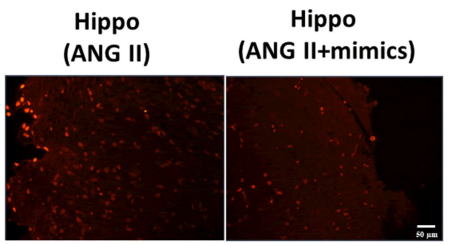

B

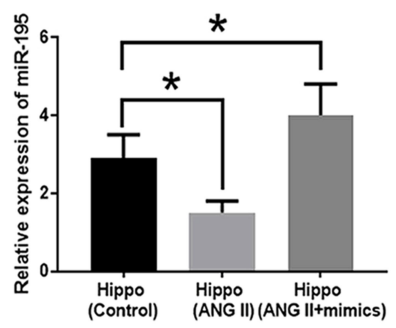

E
Bcl-2

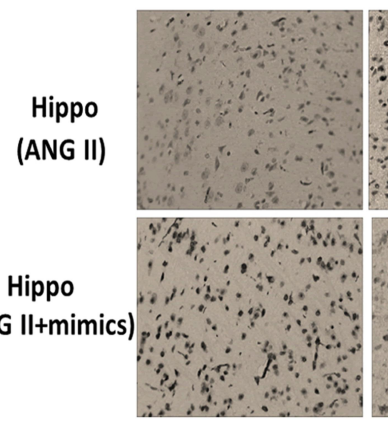

Bax

Cytc

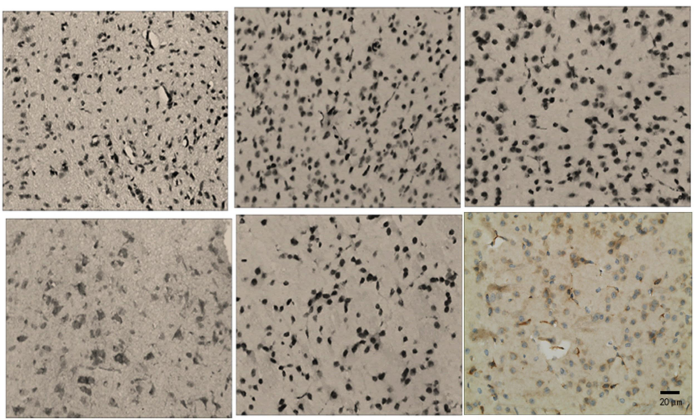

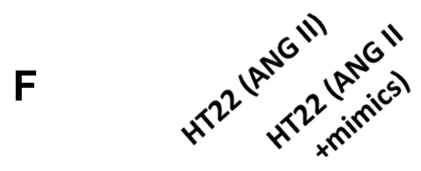

Bcl-2

Bax

Cytc

caspase-3

$\beta$-actin
G

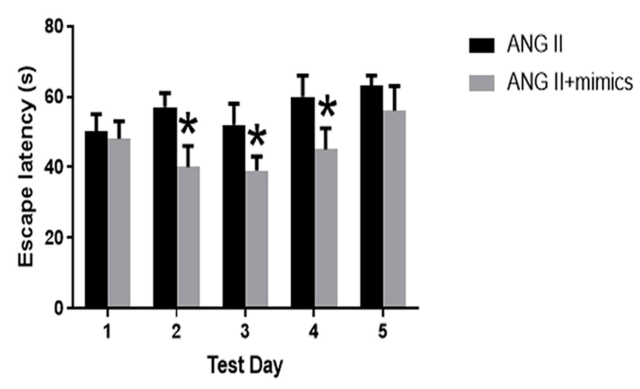

H

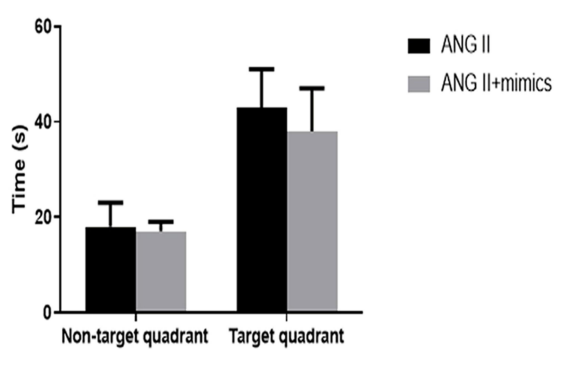

Figure 4 Effect of miR-195 on hippocampal apoptosis. (A and B) MiR-195 expression was measured by RT-PCR in miR-195 mimics-treated HT22 cells (HT22) and hippocampal tissues (Hippo), respectively. (C) Representative images of HT22 cells stained with JC-I and the red/green fluorescence intensity ratio (scale bar=50 $\mu$ m). (D) Representative images of TUNEL staining indicating apoptotic cells in the mice hippocampal tissues (scale bar $=50 \mu \mathrm{m}$ ). (E) The expressions of apoptosis-related proteins measured by immunohistochemistry assay in HT22 cells (scale bar $=20 \mu \mathrm{m}$ ). (F) The expressions of apoptosis-related proteins measured by Western blot in the hippocampal tissues. (G) Spatial navigation testing assay. $(\mathbf{H})$ Spatial memory testing assay. The data are expressed as the means \pm standard deviation $(\mathrm{n}=6$ for each group) and asterisk $(*)$ indicate a difference at $P<0.05$.

\section{Publish your work in this journal}

Psychology Research and Behavior Management is an international, peer-reviewed, open access journal focusing on the science of psychology and its application in behavior management to develop improved outcomes in the clinical, educational, sports and business arenas. Specific topics covered in the journal include: Neuroscience, memory and decision making; Behavior modification and management; Clinical applications; Business and sports performance management; Social and developmental studies; Animal studies. The manuscript management system is completely online and includes a very quick and fair peer-review system, which is all easy to use. Visit http://www. dovepress.com/testimonials.php to read real quotes from published authors. 